\title{
JUVENTUDES E VIOLÊNCIAS: \\ IMPLICAÇÕES ÉTICAS E POLÍTICAS
}

\author{
Ana Lúcia Canetti \\ Kátia Maheirie ${ }^{\star \star}$
}

\begin{abstract}
RESUMO
O artigo realiza uma revisão bibliográfica e uma análise crítica sobre a relação historicamente construida entre juventudes e violências. O texto também convida a uma reflexão, realizada a partir do referencial teórico materialista histórico e dialético na Psicologia, sobre questões éticas e políticas implicadas na relação de jovens autores de atos infracionais com as violências vividas e praticadas por eles. Destacamos o caráter contraditório destes atos infracionais, que parecem buscar uma visibilidade e inscrição (inclusão) na cidade, porém instauram, por meio desta busca, novamente o estigma (exclusão) de "desviante", os colocando ainda mais perto de seu próprio desaparecimento e extermínio.
\end{abstract}

Palavras-chave: juventudes; violências; ato-infracional.

\section{YOUTH AND VIOLENCE: \\ ETHICAL AND POLITICAL IMPLICATIONS}

\begin{abstract}
The article does a bibliographic review and a critical analysis on the relation historically built between youth and violence. The text also invites to a reflection, made from the theoretical reference historical materialist and dialectical psychology, about ethical and political questions involved in the relation of young authors of infractions with the violence lives practiced by them. The contradictory nature of these infractions is evidenced, because they appear seek visibility and membership (enrollment) in the city, however it presents with this search, once again the stigma (exclusion) of dissidents, putting them even closer to his own disappearance and extermination.
\end{abstract}

Keywords: youth; violence; infractions.

\footnotetext{
^ Mestre em Psicologia pela Universidade Federal de Santa Catarina, psicóloga da Secretaria de Saúde do Estado do Paraná.

E-mail: lucinhacanetti@yahoo.com.br

$\star \star$ Doutora em Psicologia Social pela Pontifícia Universidade Católica de São Paulo, professora adjunta do Departamento e do Programa de Pós-Graduação em Psicologia da Universidade Federal de Santa Catarina.

E-mail: maheirie@gmail.com
} 
A preocupação acadêmica sobre a relação entre juventudes e violências não é recente. Segundo Abramo (1997), a tematização da juventude pela ótica do "problema social", que normalmente engendra aspectos relacionados à violência, é recorrente em diversos momentos históricos. Para a autora, esta articulação constante entre juventude e violência acabou colaborando para a constituição, no imaginário social, de mitos sobre a juventude como uma fase da vida com propensão a atitudes "violentas" ou "perigosas".

Este artigo propõe, portanto, realizar uma revisão bibliográfica sobre esta relação historicamente construída que, dependendo da maneira como é abordada, pode estabelecer ainda mais estigmas ou relativismos para o campo de estudos sobre juventudes e violências. Ao final do texto também é feita uma reflexão teórica, baseada na abordagem materialista histórico dialética, sobre as implicações éticas e políticas das práticas de violências de jovens na atualidade.

Mesmo tendo ciência de que adolescência é a nomenclatura empregada pelo Estatuto da Criança e Adolescente (BRASIL, 1990) ao se referir à faixa etária entre 12 e 18 anos, neste artigo é utilizado o termo jovem por concordar com a discussão realizada por Coimbra, Bocco e Nascimento (2005, p. 4), que apontam para o fato do termo "adolescência" carregar diversos instituídos, muitas vezes associados à imagem dos "teens estadunidenses, instaurando uma única e determinada forma de ser adolescente".

As autoras destacam que algumas práticas e teorias da própria Psicologia colaboraram na propagação e fortalecimento desse modelo. O uso generalizado e indiscriminado do conceito ajudou a construir a ideia de uma fase universal e ahistórica do desenvolvimento humano, naturalizando, essencializando e homogeneizando sujeitos e histórias completamente distintas. Porém, as autoras alertam:

Sabemos que a simples troca de palavras, de adolescência para juventude, não nos garante a quebra de naturalizações, uma vez que, sendo o conceito de juventude uma construção social, pode também ser instituído e capturado. No entanto, a aposta nas multiplicidades e diferenças para questionar o conceito de adolescência pode funcionar como uma estratégia contra as capturas e produções impostas por saberes que se apóiam em uma realidade normatizada, que eliminam a possibilidade do acaso e que se pretendem neutros. Quando definimos alguém como adolescente, podemos estar colocando em suspenso suas multiplicidades de existência e construindo uma definição que impede que os desenhos de novos fluxos e de vida ganhem força de expansão. (COIMBRA; BOCCO; NASCIMENTO, 2005, p. 8).

Da mesma maneira, para que não se naturalize a própria noção de juventude ou que o conceito seja novamente capturado, é importante enfatizar que essa também não é um dado natural, e sim um advento da modernidade. Segundo Groppo (2000, p. 8): 
[...] trata-se não apenas de limites etários pretensamente naturais e objetivos, mas também, e principalmente, de representações simbólicas e situações sociais com suas próprias formas e conteúdos que têm importante influência nas sociedades modernas.

Para o autor, a criação da juventude é um dos fundamentos da modernidade, e tem uma importância crucial para o entendimento das características das sociedades modernas, de seu funcionamento e de suas transformações.

Peralva (1997) afirma que as idades da vida, embora sejam ancoradas no desenvolvimento biopsíquico dos indivíduos, não são fenômenos puramente naturais, e sim sociais e históricos, datados e inseparáveis do processo de constituição da modernidade. A cronologização do curso de vida e a homogeneidade etária respondem, segundo Groppo (2000) às necessidades de uma civilização que constroi esferas sociais regidas por relações universalistas ou de um mercado de trabalho fundado no indivíduo livre e não mais na contratação da família.

Àries (1981), também colabora, em seu estudo sobre a história da criança e da família, desmistificando a concepção naturalizante da cronologização do curso de vida. Peralva (1997) destaca que o trabalho de Áries constitui provavelmente o marco mais importante no sentido dessa tomada de consciência: do caráter tardio da emergência do sentimento de infância e de sua natureza eminentemente moderna. Os estudos de Áries (1981) demonstram que não existia, até o final da Idade Média, o sentimento moderno de infância dentro do núcleo familiar. Seu estudo vai esclarecer como, na vida social medieval, não se distinguiam os indivíduos por faixas etárias ou grupos de idade e como infância ou juventude são criações modernas, que têm a escola, trabalho ou a família, por exemplo, como principais instituições que colaboram no sentido de instituir a vida em etapas.

Por ser uma construção social, a juventude também foi vista de diferentes maneiras conforme os períodos históricos ou sociedades na qual foi analisada. Contudo, Abramo (1997) afirma que os jovens sempre foram objetos de atenção quando vistos como agentes de ruptura social, de ações violentas ou como ameaças para si mesmos ou para a sociedade. Dayrell (1999) também afirma que ora os jovens foram vistos como problemas (drogas, violência), ora como espetáculo (exótico).

Em se tratando da relação entre juventude e violência, por exemplo, estas categorias apareceram juntas ou até mesmo sobrepostas nos discursos acadêmicos; o que colaborou para que se construíssem tanto generalizações que homogeneizaram juventudes ${ }^{1}$ de espaços, tempos e classes sociais distintas, quanto contribuíram para tornar violência, conforme Rifiotis (2006), um significante vazio que pode acolher vários significados e situações.

Rifiotis (2006) afirma que "violência" pode ter inúmeras designações e que, através de um processo de homogeneização, o termo acabou tornando-se um adjetivo que designa tudo que tenha atribuição de valor negativo. Para o autor, a violência é um tema que normalmente engendra um automatismo moral pela negatividade, que pode levar ao maniqueísmo e à estigmatização. 
Zaluar (1999, p. 28, grifo da autora) afirma:

A dificuldade na definição do que é violência e de que violência se fala é o termo ser polifônico desde a sua própria etimologia. Violência vem do latim violentia, que remete a vis (força, vigor, emprego da força física ou os recursos do corpo em exercer a sua força vital). Essa força torna-se violência quando ultrapassa um limite ou perturba acordos tácitos e regras que ordenam relações, adquirindo carga negativa ou maléfica. É, portanto, a percepção do limite e da perturbação (e do sofrimento que provoca) que vai caracterizar um ato como violento, percepção essa que varia cultural e historicamente.

A polifonia/polissemia do conceito e o fato de variar cultural e historicamente provocam diversas interpretações do limite do que é considerado violento. Zaluar (1999, p. 43) cita algumas interpretações do conceito como, por exemplo, "ausência de compaixão" ou "excesso de poder". Menciona que, para Arendt, os instrumentos da violência seriam mudos, abdicariam do uso da linguagem, o que caracteriza as relações de poder baseadas na persuasão, influência e legitimidade. Violência também pode significar para Brant (apud ZALUAR, 1999, p. 43) a negação da dignidade humana e, para Tavares dos Santos (apud ZALUAR, 1999, p. 43), dispositivos de controle, abertos e contínuos. Zaluar (1999, p. 43) continua citando que, para Adorno e Cardoso, a violência significaria o não reconhecimento do outro, a anulação ou cisão do outro. Entretanto, mesmo com diferentes interpretações, Zaluar $(1999$, p. 43) destaca que, em todas estas definições ressalta-se abertamente ou não:

[...] o pouco espaço existente para o aparecimento do sujeito da argumentação, da negociação ou da demanda, enclausurado que fica na exibição da força física pelo seu oponente ou esmagado pela arbitrariedade dos poderosos que se negam ao diálogo.

Mesmo Sánchez Vázquez (2007) que, a partir da teoria marxista, vê a importância da violência para a transformação social, afirma a necessidade da abolição da mesma. Essa teoria afirma a necessidade da violência na práxis revolucionária, já que todas as mudanças sociais não prescindiram da violência. Entretanto, não faz uma apologia à mesma, pois acredita que só a práxis social deixando de ser violenta terá uma dimensão verdadeiramente humana.

O autor afirma existir violência porque há contradições antagônicas irreconciliáveis nesta sociedade dividida em classes:

Na sociedade baseada na exploração do homem pelo homem, como é a sociedade capitalista atual, a violência não só se mostra nas formas diretas e organizadas de uma violência real ou possível, como também se manifesta de modo indireto, e aparentemente espontâneo, como violência vinculada com o 
caráter alienante e explorador das relações humanas. Tal é a violência da miséria, da fome, da prostituição ou da doença que já não é resposta a outra violência potencial ou em ato, mas sim a própria violência como modo de vida porque assim o exige a própria essência do regime social. (SÁNCHEZ VÁZQUEZ, 2007, p. 377-378)

Contudo, para este mesmo auto a "não violência" não poderá anular as violências estabelecidas por esta sociedade. A violência revolucionária, portanto, acaba sendo uma necessidade histórica que desaparecerá ao desaparecerem as condições histórico-sociais que a engendram: "a violência revolucionária que hoje contribui para criar esse estado futuro de coisas, na verdade, é potencialmente a negação de si mesma e, nesse sentido, é como sua própria negação, a única violência legítima" (SÁNCHEZ VÁZQUEZ, 2007, p. 391).

Assim, nessa visão, a violência é ambivalente, não sendo pura positividade, nem mera negatividade. Sánchez Vázquez (2007, p. 392) afirma que ela é positiva na medida em que é práxis revolucionária diante desta sociedade dividida em classes, mas é negativa, pois "em um mundo verdadeiramente humano, onde os homens se unam livre e conscientemente, a violência tem de ser excluída".

Rifiotis (2006) identifica três tipos de discursos no campo de estudos sobre a violência: aqueles que se colocam contra a violência, o da própria violência (como linguagem social) e o discurso analítico, que trata as violências como expressões sociais ou produtividades. No caso, o autor se identificaria com este terceiro campo e acredita que nos discursos contra "a violência", corre-se o risco de se realizar uma adesão à indignação, que pode transformar as falas em exclusivamente denúncias, ocupando o lugar que deveria ser de análise sobre o tema. Por meio da indignação, há uma adesão ao tema pela emoção, o que pode limitar o olhar e contribuir para a construção de um discurso de exterioridade e vitimização na análise (RIFIOTIS, 1997, 2006).

Segundo Rifiotis (2006), as categorias vítima e agressor, utilizadas a partir dos discursos da indignação e vitimização, acabam obliterando a própria vítima e simplificando as relações sistêmicas que se fazem presentes em qualquer evento. Isso pode cooperar para a ampliação de discursos que buscam soluções na judicialização, ou acabam desvalorizando outras formas de sociabilidade. $\mathrm{O}$ autor reforça: “ao invés de acreditar que existe algo como 'a violência' em relação à qual 'agressores' e 'vítimas' se comportam, deveríamos procurar ver como as coisas acontecem concretamente" (RIFIOTIS, 1997, p. 16, grifos do autor).

Sales (2007) destaca que, muitas vezes, situações ditas "violentas" são vistas como eventos individuais de incivilidade, irracionalidade ou até mesmo da ordem do animal, bárbaro ou selvagem. Ao reduzir o comportamento violento ao nível biológico-individual, a autora acredita que se individualiza o ato delituoso, o des-socializando e des-historicizando. "O grande risco é, pois, perceber a violência apenas como atitude extremada, autônoma e destruidora em si, sem nexos societários ou responsáveis. Cabe, portanto, não perder a sua dimensão sóciocultural, ou política e social"' (SALES, 2007, p. 288). 
Há uma tentativa de explicação biologizante para atos e manifestações demasiadamente humanos, pois estes são:

[...] expressão de um sem número de tensões sócioeconômicas e culturais, de contradições intersubjetivas, e outras tantas individuais ligadas a conflitos morais e/ou sofrimento psíquico, inscritos sempre numa forma específica de civilização e fomentados por relações sociais mais amplas (SALES, 2007, p. 214).

Sales (2007) também aponta para a associação entre violência e loucura concepção corrente na psiquiatria desde o século XIX -, e para a discussão sobre a diabolização como explicações para atos violentos. Para Zaluar (apud SALES, 2007) há um retorno à ideia do bem e mal, onde o nome do diabo passa a ser invocado cada vez mais para dar sentido às experiências de violência. Ainda, destaca que os próprios bandidos, identificados pessoal e profundamente com esta encarnação do mal, reinterpretam suas ações a partir de um pacto fictício com ele. Uma forma de tratar um evento social com exterioridade e novamente carregado pelo aspecto da negatividade.

Em confluência à temática da violência, o caráter de negatividade e exterioridade também está presente nos discursos sobre os jovens. Abramo (1997, p. 89) afirma: "a acentuação da atenção nas dimensões de vitimização e heteronomia frente às lógicas do sistema, acaba por manter invisível, e impensável, qualquer tipo de positividade das figuras juvenis". Principalmente a partir dos anos 1990, a imagem do jovem é permeada pela aparência de ameaça à integridade social ou como vítima das fraturas sociais. Os sentimentos em relação aos jovens acabam girando em torno do medo ou da compaixão, mantendo o caráter de exterioridade nos discursos. Os jovens transitam entre a imagem de vítima ou de agressores.

Abramo (1997) afirma que os jovens acabam normalmente sendo vistos como heterônomos e nunca como autores reais de suas ações. Rabello de Castro (2001) também discute que a partir de um referencial evolutivo ou desenvolvimentista a criança ou o jovem sempre foram vistos como seres incompletos e sem capacidade de participar plenamente da vida social, o que faz com que sejam vistos como seres incapazes de se tornarem sujeitos no sentido pleno da palavra.

Há, segundo Abramo (1997) uma dificuldade de ir além da sua consideração como "problema social" e de incorporá-los como capazes de formular propostas ou transformações sociais. Nos discursos sobre os jovens como "problemas sociais", juventude passa a significar negatividade, incompletude, risco, falha, disfunção ou anomia no processo de integração social. Adjetivos que também são muito presentes quando se fala de violência.

Abramo (1997) afirma que não é por acaso que a problematização sobre a juventude é uma problematização moral: o foco real de preocupação acaba sendo com a coesão moral da sociedade e com a integridade moral do indivíduo, de modo funcional na sociedade. É nesse sentido que, na maior parte das vezes, a 
problematização social da juventude é acompanhada do desencantamento, ou de uma espécie de "pânico moral", que condensa os medos e angústias relativos ao questionamento da ordem social, como conjunto coeso de normas sociais.

Esse desencantamento apresenta tanto a juventude como a violência como categorias que ensejam questões relativas à crise presente na modernidade. Rifiotis (2006) afirma que o campo de estudos sobre violência é um território estratégico para os discursos da contemporaneidade e um lugar central na compreensão do presente, das brechas e da crise da modernidade.

Em relação à juventude Abramo complementa:

A "juventude" tem estado presente, tanto na opinião pública como no pensamento acadêmico, como uma categoria propícia para simbolizar os dilemas da contemporaneidade. Ajuventude, vista como categoria geracional que substitui a atual, aparece como retrato projetivo da sociedade. Nesse sentido, condensa as angústias, os medos assim como as esperanças, em relação às tendências sociais percebidas no presente e aos rumos que essas tendências imprimem para a conformação social futura (ABRAMO, 1997, p. 79, grifo da autora).

Os dilemas, angústias e medos ficam ainda mais aparentes quando se fala das juventudes das classes populares. A imagem do "violento" ou "perigoso", ou o principal foco de "pânico social" está normalmente associada aos jovens pobres (COIMBRA; NASCIMENTO, 2003).

Sales (2007, p. 205) destaca que os jovens pobres e/ou autores de ato infracional estão no cerne dos debates atuais sobre a questão da violência, da cultura, sociabilidade, justiça e direitos humanos. Para a autora, as performances destes jovens, que não estão visualizando perspectivas para seus futuros, são geradoras de reações, ações de visibilidade e medo pela mídia, elevando-os a condição de "metáforas da violência" na atualidade.

Limitar os problemas sociais de nossa realidade às ações juvenis é colaborar ainda mais para que se construam estereótipos e ideologias no campo dos estudos sobre as juventudes. Além disso:

[...] essa atitude desresponsabiliza o mundo adulto da necessidade de compreender a complexidade do fenômeno da violência e as determinações da criminalidade, cujas respostas devem ser parametradas pela construção de projetos de futuro para as novas gerações (SALES, 2007, p. 316).

Zaluar $(1999,1997)$ debate os riscos de uma causalidade linear entre pobreza e violência, pois, na realidade, são pouquíssimos os jovens pobres que enveredam pela carreira criminosa. A pergunta sobre os motivos que levariam um jovem pobre a recorrer à criminalidade deveria ser invertida. Diante das desigualdades sociais, fetichização das mercadorias e a busca desenfreada pelo 
consumo, a verdadeira pergunta seria: por que a maior parte dos jovens das periferias urbanas não enveredam para o mundo do crime? Por que em sua maioria esses não escolhem a criminalidade?

A vinculação linear entre pobreza e violência possibilitou que se criassem no "combate à violência" dicotomizações entre políticas de direitos humanos versus lei e ordem, políticas sociais versus segurança pública ou políticas públicas de prevenção versus repressão. Zaluar (1999, p. 76) destaca que:

[...] as políticas sociais devem ser implementadas, não porque os pobres constituem um perigo permanente à segurança ou à ordem pública, não porque venham a ser as classes perigosas, mas porque um país democrático e justo não pode existir sem tais políticas.

Portanto, rever as visões sobre juventude ou a complicada relação entre as categorias juventude, pobreza e violência torna-se pertinente principalmente neste momento, em que retornam os discursos conservadores sobre os "desvios" dos jovens pela droga, violência, envolvimento com a criminalidade ou comportamentos "antissociais". Abramo (1997) destaca que reaparecem, no cenário contemporâneo, elementos de análise característicos dos anos 1950, quando havia uma concentração da atenção nos problemas de comportamento, que se pressupunha que levariam a situações de "desvios" na "integração social". Nessa época, a transgressão ou a delinquência eram quase que tratadas como inerentes à condição juvenil.

Já nos anos 1960 e parte dos anos 1970, os discursos traziam a ideia de uma geração de jovens que também ameaçavam a ordem social, porém nos âmbitos políticos, culturais e morais. Entretanto, mesmo os jovens ganhando categoria de críticos à ordem estabelecida, ou portadores da possibilidade de transformação, eles eram vistos mais como uma fonte de energia utópica, do que propriamente capazes de efetivamente realizar tal transformação (ABRAMO, 1994).

A autora relata que muitos setores políticos, críticos à ordem estabelecida (como os partidos comunistas e organizações sindicais tradicionais), interpretavam as manifestações juvenis da época como ações inconsequentes, quando não ameaçadoras de um processo mais sério e eficaz de negociações para transformações. Mesmo assim, há uma reelaboração positiva da juventude nessa época, que fixou um modelo ideal no qual a rebeldia, o idealismo, a inovação e a utopia tornaram-se características essenciais desta faixa etária (ABRAMO, 1997). Isso fez com que nos anos 1980, os jovens, em oposição à geração dos 1960 e 1970, fossem considerados patológicos, com comportamentos individualistas, apáticos, consumistas, conservadores e indiferentes aos assuntos públicos ou políticos.

Segundo Abramo (1997), a partir dos anos 1990, não é mais a apatia que chama a atenção. O olhar se volta para as ações dos jovens nas ruas. Há, segundo Diógenes (1998), uma fragmentação de "rebeliões", onde o cenário urbano 
é marcado pela agressividade real e simbólica do comportamento juvenil, além de uma ainda maior diversificação de ações que se apresentam como formas de buscar reconhecimento na cidade.

Nos anos 90, as figuras juvenis mais em evidência são os jovens pobres que parecem nas ruas, divididos entre o hedonismo e a violência: meninos de rua, jovens infratores, gangues, galeras, tribos; e, principalmente, jovens em "situação de risco" (risco para si próprios e para a ordem social), dos quais aqueles envolvidos no tráfico, matando e morrendo muito cedo, são uma das imagens mais dramáticas e ameaçadoras dos nossos tempos (ABRAMO, 1997, p. 86, grifo da autora).

Estas figuras "ameaçadoras" ou "dramáticas" se fazem presentes em um momento que há, no cenário contemporâneo brasileiro, segundo Oliveira (2001), uma situação peculiar, graças a uma onda jovem demográfica, que conta com cerca de 51 milhões de jovens no país, e um forte acirramento das desigualdades sociais, que faz com que a maioria jovem esteja em situação de pobreza.

Coimbra e Nascimento (2003), afirmam que muitos desta juventude pobre e marginalizada vêm criando e inventando outros mecanismos de sobrevivência e luta, resistindo às exclusões e destruições que vivenciam diariamente em seu cotidiano.

Sánchez-Jankowski (1997), em um estudo sobre as gangues, também afirma que estas são organizações que tentam dar uma resposta coletiva a uma situação econômica de grande penúria e isolamento. Há, em sua opinião, uma elaboração de estratégias racionais de sobrevivência que se aplicam no estabelecimento de relações com seu ambiente, com organizações rivais, polícia, sistema político ou com a mídia.

Diógenes (1998) também destaca que o principal objetivo das gangues é buscar uma inscrição na cidade e modos de construção da visibilidade. A ação violenta das gangues seria somente um dos métodos utilizados para se atingir este objetivo. Contudo, a violência não é vista pela autora como ação exclusiva de jovens que pertencem a gangues. Em outros agrupamentos (hip hop ou galeras, por exemplo) também estão presentes ações consideradas violentas. Esses atos, como outros considerados não violentos, são mecanismos que constituem identidades ou formas de "se garantir" e se proteger.

Sales (2007) aponta também para a atuação infracional como uma forma de se conquistar visibilidade. A violência se torna um valor e uma condição de reconhecimento na contemporaneidade. Afirma que os jovens gostam de ser vistos associados à beleza e irreverência e buscam reconhecimento e prestígio social diante da impossibilidade de gratificação imediata em termos de consumo, prazer e lazer. Os jovens infratores compreenderiam o poder e a força da imagem que os associa à rebeldia, a comportamentos transgressores ou à violência. Além disso, em sua opinião, estes jovens entenderiam que a sociedade somente atende seus direitos em situações limites, como revoltas, rebeliões ou ações violentas. 
Contudo, o drama de muitos destes jovens é o desejo de ser visível e ao mesmo tempo o sofrimento de ser "visto demais" ou "mal-visto", por meio de uma indesejada "visibilidade perversa". Sales explica que:

De um lado, a invisibilidade do sofrimento por que passam crianças e adolescentes das classes trabalhadoras nas suas áreas de moradia e socialização, não bastassem as privações materiais, culturais e, muitas vezes, afetivas às quais são submetidos. De outro, sinalizam o tipo de malhas simbólicas e ideológicas que permitem a visibilidade dos adolescentes, uma visibilidade intensificada pelo preconceito e medo da violência, balizados apenas em características físicas, sociais e geográficas, supostamente reveladoras da periculosidade dos seus portadores. Trata-se, portanto, de uma condição de visibilidade perversa, seletiva e reprodutora de discriminações históricas contra os setores mais pauperizados e insubmissos das classes trabalhadoras urbanas. (SALES, 2007, p. 27).

Assim, pode-se observar que a própria visibilidade é uma condição contraditória, pois ao mesmo tempo em que é produto das relações de poder, atingi-la não significa maior reconhecimento ou ultrapassar as discriminações. Como afirma Sales (2007), pode se saltar da "invisibilidade" à "visibilidade perversa".

Mesmo assim, há um desejo, por parte dos jovens de visibilidade e projeção social. Diante do fenômeno da fetichização das mercadorias ou da lógica da propriedade privada (fomentadora do desejo consumista) em cenários sociais marcados pela pobreza e pela miséria, "uma outra possibilidade que se abre para toda uma gama de sujeitos é a ruptura com a lei, por meio de ações delituosas, violentas ou não". (SALES, 2007, p. 101).

Em algumas letras de Rap se escuta: "O que cê qué, viver pouco como um Rei, ou então muito, como um Zé?" (BROWN, 2002) ou "Eu queria vê se você fosse operário, desse aquele trampo prá ganhá um só salário, ela ía querer você, bem longe dela" (TRILHA SONORA DO GUETO, 2004). Há nestas letras uma desvalorização do assalariado ou do operário, visto como um Zé (mané), que não tem condições de, com o seu parco salário, ser aceito ou valorizado. Sales (2007, p. 210) comenta sobre dois caminhos utilizados pelas classes populares para se tentar atingir o consumo: um pela "sujeição" e o outro pela "rapidez". O primeiro é mais longo, penoso, pautado no sistema de compra a prazos ("vive-se muito como um Zé"). No segundo, busca-se exibição, poder, privilégios e se vive a consigna: "o que vem fácil vai embora mais fácil ainda" ("viver pouco como um Rei").

Ainda que pela via da transgressão ou do delito, alguns jovens estão em busca de singularização, aceitação e visibilidade social. Contudo, Sales (2007, p. 95, grifos da autora) lembra que estes jovens 'desejam o 'bom', enfeitiçados pelo mundo das mercadorias -, mas também provam do seu 'pior' - a alienação do desejo, a privação e a expulsão como párias da nova ordem econômica". Cassab (2001) afirma que as estratégias por meio da ação delituosa também não rompem com o caráter de subalternidade presente na origem de classe destes jovens. "As 
tentativas de inclusão em certo sentido reforçam as leis ou valores contra as quais se insurgem. Isso retira qualquer dúvida sobre a existência de um caráter de transformação social no crime organizado". (CASSAB, 2001, p.217)

A ação infracional mostra, portanto, toda a sua contradição, ${ }^{2}$ pois na busca de inscrição (inclusão) na cidade, instaura novamente o estigma (exclusão). Ela pode ser uma forma de produção social encontrada pelos jovens para tentar enfrentar o não oferecimento de espaços de visibilidade, porém, na realidade, mantém o estigma de "desviante", os colocando ainda mais perto de seu próprio desaparecimento e extermínio.

Zaluar (1999) atenta para os riscos do relativismo em relação ao tema da violência. Para ela, quando se trata a violência como um fundamento da vida social e não se reconhece à violência como um mal a se combater, acaba se fazendo uma recusa em condenar a violência estendida a todas as suas formas (policial, corrupção, violência social, urbana, entre outras). Em sua opinião (ZALUAR, 1999), ao tratar a violência como produtividade ou modo de operar das classes subalternas, algumas teorias "apelaram para uma estetização da violência, que chegou a ser apresentada como saída para a dominação, a exploração, a exclusão dos dominados, explorados e excluídos" (ZALUAR, 1999, p. 21).

A autora cita que, para alguns autores, como Diógenes (1998) e Rifiotis (1997), a manifestação pública da violência ganharia positividade ao instaurar diferenças, pois quando os moradores dos bairros periféricos registram sua existência, tornariam públicas as suas redes de exclusão social. Contudo, há que se ter muito cuidado ao se propor esta "instauração de diferenças", para que não se faça, conforme Amorim (2007), a partir de um discurso que busca elogiar a diferença, um elogio à indiferença. Ou também não se faça a defesa da diversidade como ocultamento da desigualdade social.

A sociedade neoliberal e o sujeito pós- moderno relativizaram todos os valores, inclusive aqueles que visavam distinguir práticas igualitárias e pautadas por um princípio de justiças social das práticas mercadológicas pautadas pelo critério do lucro. [...] Reconhecer um discurso diverso e um sentido singular não deve impedir que se examine a relação de forças desiguais que o produziu e que o atravessa (AMORIM, 2007, p. 13).

Além disso, Zaluar (1999) destaca que este discurso que busca "instaurar diferenças" produz a dicotomização de dois mundos - o dominante e o marginal; o incluído e o excluído. A autora assinala que, desta maneira, corre-se o risco do mundo do desviante, marginal ou divergente se apresentar como alternativa ao mundo oficial, e como tal seja justificado. 
Zaluar (1999) critica esta postura, pois acredita que estas teorias em nome da defesa da existência e da importância do conflito, da desordem e do dissenso, compreendem e justificam as manifestações de violência na sociedade brasileira contemporânea, sem ficar claro se incluiriam nessa positividade também os homicídios cometidos pelos jovens entre si ou contras seus vizinhos.

Por mais que a violência corte transversalmente a sociedade, ela vitima concreta e excessivamente as camadas mais pauperizadas das classes trabalhadoras. (SALES, 2007). Para Soares (apud SALES, 2007), engana-se quem acredita que a vitimização letal se distribua democraticamente, cruzando fronteiras de classe, pois os pobres são as principais vítimas da criminalidade violenta.

Para Zaluar (1999), os efeitos maléficos da violência sobre os jovens e seus vizinhos tornam-se cada vez mais complexos, por serem os jovens pobres simultaneamente os autores e vítimas de alguns crimes violentos. Segundo Waiselfisz (2006), as principais vítimas de homicídio no país são os jovens homens, pobres e em sua maioria, negros. Há $85 \%$ a mais de vítimas negras do que brancas e 93,7\% são homens, dentro da população jovem vítima de homicídio. Em 2004, 51 jovens foram mortos por dia no Brasil, significando mais mortes do que nos dois anos da guerra da Chechenia, Rússia ou da guerra que durou 24 anos, na Guatemala. Nesta última guerra, morreram 16.000 pessoas por ano e, aqui no Brasil, morrem 48.000. Foram a óbitos mais jovens por homicídios no Brasil do que nas guerras de extermínio do Golfo, em El Salvador, Angola ou Guatemala. (WAISELFISZ, 2006)

Mesmo reconhecendo a gravidade destes dados, é importante destacar que as violências sofridas pela maioria dos jovens brasileiros não se resumem somente às agressões físicas ou riscos de homicídios. Sales (2007) aponta para o fato destes jovens viverem uma "cidadania escassa", em que se vive também cotidianamente a violência social de não se ter perspectivas de futuro ou possibilidades de trabalho, lazer, cultura, esporte, educação.

A violência é, pois, manifestação do poder, expressão de como as relações sociais aqui organizadas, de como o capitalismo se engendrou e se perpetua no país. É exploração, opressão e dominação, mas não é somente força pura, é também ideologia e sutileza (SALES, 2007, p. 59).

Estas violências (miséria, desemprego, desigualdade, exploração, falta de saúde, educação ou ausência de políticas sociais), foram chamadas de "violências estruturais" e eram temas de debates principalmente na década de 1970 no Brasil (ZALUAR, 1999, 1997).

Sales (2007) fala da necessidade de não se relativizar a violência como um problema. Porém, afirma que é necessário historicizá-la e compreender seu papel na contemporaneidade, não colaborando ainda mais para a "cultura do medo", que é construída muitas vezes pela mídia e torna o tema espetacularizado. A "cultura do medo" valoriza o pânico das classes médias e altas em relação à violência, porém obscurece os medos que crianças e jovens pobres sentem diariamente a 
partir da ação do traficante ou da polícia. Zaluar (1999) afirma que a "cultura do medo" auxilia ações despóticas ou mais repressivas como a pena de morte, por exemplo, e também faz do jovem pobre o bode expiatório da crise social e política, construindo a nova figura do bandido, através de uma imagem diabólica, desumana, monstruosa associada ao criminoso violento.

O tema da violência juvenil mobiliza diversas questões éticas e políticas. Falar sobre juventude, provoca reflexões sobre o futuro de uma sociedade. Tratar do tema da violência também ascende questões sobre as relações vividas em uma sociedade regida pela lei da guerra e da exploração.

Assim, não se pode negar ou relativizar que estas dinâmicas violentas, tanto de viver uma "cidadania escassa", quanto de correr risco de morte, fazem sofrer e que esses são problemas reais dos jovens brasileiros na atualidade. Não há também como se recusar a ver que as violências, na qual os jovens estão submetidos, causam sofrimentos como o medo ou a incerteza de se estar vivo no dia seguinte.

Quando se analisa a questão da violência juvenil, é importante que não se colabore ainda mais com a "cultura do medo", porém, também que não se relativize o tema e os problemas sociais decorrentes do mesmo. Um problema que já virou da ordem da saúde pública (MINAYO, 1990, 2006) com o crescimento real das mortes violentas, sendo a segunda maior causa de mortes no país, com $65 \%$ das causas de mortalidade entre jovens de 15 e 19 anos e $59 \%$ entre 25 a 29 (ZALUAR, 1999).

Igualmente, não é possível promover um embelezamento da pobreza, da miséria ou da criminalidade. A participação de jovens no "mundo do crime" não se apresenta como saída para uma vida digna ou de combate ao sistema capitalista. Zaluar critica teorias que acabaram considerando a criminalidade como forma de resistência à ideologia dominante:

Nessas mortes, os pobres não estão cobrando dos ricos, nem estão perpetrando alguma forma de vingança social, pois são eles as principais vítimas da criminalidade violenta, pela ação da polícia ou dos próprios delinqüentes. Vivem, de fato, segundo as regras da vingança privada, graças à predominância de um etos guerreiro e à ausência de uma instância jurídica, estatal ou não, na resolução de conflitos. (ZALUAR, 1999, p. 68)

A ação criminosa ou infracional, que por vezes é empreendida por jovens, surge como uma objetivação que anseia por novas formas de subjetivação. Buscase uma possibilidade de existência real e simbólica pela via infracional. Contudo, estes jovens autores de atos infracionais acabam fazendo do outro seu objeto, não se transformando, de fato, as relações desta sociedade que, tipicamente, buscam coisificar sujeitos. Além disso, não conseguem transformar efetivamente suas condições econômicas, sendo, muitas vezes, a ação infracional, mais uma forma de contribuir para seu extermínio, quando é morto ou apreendido pela polícia e passa a ser mais um jovem privado de liberdade, encarcerado. 
Para concluir, Amorim $(2007,2002)$ apresenta uma discussão importante sobre algumas pesquisas realizadas na década de 1970, que trabalhavam com crianças em situação de rua. Estas pesquisas, na opinião da autora, acabaram positivando as diferenças destas crianças para desfazer preconceitos que tratavam sempre as diferenças como incapacidades e não como fontes ricas de aprendizado. Porém, para a autora, estas análises impediram que fossem analisadas as perdas subjetivas dessas crianças.

Com o agravamento da miséria e da desigualdade entre pobres e ricos na década de 1990, Amorim (2007) destaca que foi necessário rever estas teorias. As crianças em situação de rua não estavam mais diante somente de ameaças de mortes simbólicas, mas vivendo com condições extremamente violentas, de marginalização extrema e correndo risco de vida.

Não houve como relativizar que algo de muito grave estava se produzindo na subjetividade destas crianças quando em situação de rua. A autora afirma que na maioria das pesquisas que ela analisou, a criança que vive nas ruas era idealizada pelo pesquisador como sendo autônoma e livre por estar longe do controle das instituições do Estado. Porém, "estar o dia inteiro exposta ao perigo e submetida inteiramente à lógica da sobrevivência não deve ser tratado como uma simples diferença cultural em relação á criança rica" (AMORIM, 2007, p. 23). Isso não quer dizer que se deva idealizar a criança rica como se sua condição material favorecida garantisse obrigatoriamente a facilitação ou a riqueza do ponto de vista subjetivo, pois outras violências e perdas igualmente podem também estar se produzindo nessa camada social.

Amorim (2007, p. 25) ainda afirma que, ao se referir aos segmentos explorados e excluídos da sociedade - como era o caso das crianças em situação de rua ou como é o caso de muitos jovens autores de atos infracionais - "o politicamente correto utiliza eufemismos, palavras gentis e polidas, como se num ato performativo do discurso, pudesse assim ocultar a desigualdade da relação e apaziguar o conflito".=

No caso dos jovens evolvidos no dia-a-dia do tráfico, da prática de roubos ou de homicídios, que vivem permeados por diversas formas de violências, também não é possível apaziguar suas dificuldades ou seus sofrimentos ético-políticos (SAWAIA, 2006). Não é aceitável se falar, por exemplo, através do discurso politicamente correto, que a vida infracional é somente um "estilo diferente" de viver. Isso só produziria mais violências a estes jovens. Não há como negar os sofrimentos destes jovens ou os das vítimas que eles já violentaram. Não há como tratar como "diferenças" as suas vidas de miserabilidade, múltiplas violências ou a falta de perspectivas de futuro. Desta maneira, como afirma Amorim (2007), a "diferença" tornar-se puro signo de "desigualdade", sendo puro efeito da opressão e da miséria, onde não está se constituindo diversidades geradoras de produções simbólicas ricas, mas realidades paralisadoras do pensamento e da atividade criadora. 


\section{Notas}

${ }^{1}$ Novaes (1997) e Abramo (1997) destacam o uso do termo juventude no plural na intenção de não tornar homogêneas juventudes de contextos e momentos históricos completamente distintos.

${ }^{2} \mathrm{O}$ conceito de contradição, baseado na teoria materialista histórico dialética, é utilizado por dar conta de enfatizar o aspecto dialético e não linear do processo de exclusões/inclusões vividos pelos jovens que infracionam.

\section{REFERÊNCIAS}

ABRAMO, H. W. Cenas juvenis: punks e darks no espetáculo urbano. São Paulo: Página Aberta, 1994.

ABRAMO, H. W. Considerações sobre a tematização social da juventude no Brasil. Revista Brasileira de Educação, Campinas, n. 5, p 25-36, maio/ago. 1997. Número especial: Juventude e Contemporaneidade.

AMORIM, M. Vozes e silêncio no texto de pesquisa em Ciências Humanas. Caderno de Pesquisa, São Paulo, n.116, p. 7-19, jul. 2002.

AMORIM, M. A contribuição de M. Bakhtin: a tripla articulação ética, estética e epistemológica. In:_. Ciências Humanas e Pesquisa: leituras de Mikhail Bakhtin. São Paulo: Cortez, 2007. p. 11-25.

ARIÈS, P. História Social da Criança e da Família. Rio de Janeiro: LTC, 1981.

BRASIL. Estatuto da Criança e do Adolescente. Lei 8069, de 13 de julho de 1990. Brasília, 1990.

BROWN, M. Vida Loka II. In: RACIONAIS MC'S. Nada como um dia após o outro dia. São Paulo: Unimar Music, p2002. 2 CDs. Disco 2. Faixa 7.

CASSAB, M. A. T. Jovens pobres e a cidade: a construção da subjetividade na desiguladade. In: . Crianças e jovens na construção da cultura. 1. ed. Rio de Janeiro: FAPERJ, 2001. p. 209-226. v. 1.

COIMBRA, C. C.; NASCIMENTO, M. L. Jovens pobres: o mito da periculosidade. In: . Jovens em tempo real. Rio de Janeiro, DP\&A, 2003. p. 19-37.

COIMBRA, C. C.; BOCCO, F.; NASCIMENTO, M. L. Subvertendo o conceito de adolescência. Arquivos Brasileiros de Psicologia, Rio de Janeiro, v. 57, n. 1, p. 2-11, 2005.

DAYRELL, J. T. Juventude, grupos de estilo e identidade. Educação em Revista, Belo Horizonte, n. 30, p. 459-470, dez. 1999. 
DIÓGENES, G. Cartografias da cultura e da violência: gangues, galeras e o movimento hip-hop. São Paulo: Annablume, 1998.

GROPPO, L. A. Juventude: ensaios sobre sociologia e história das juventudes modernas. Rio de Janeiro: DIFEL, 2000.

MINAYO, M. C. S. A violência na adolescência: um problema de saúde pública. Cadernos de Saúde Pública, Rio de Janeiro, v. 6, n.3, p. 278-292, jul./set. 1990.

MINAYO, M. C. S. A inclusão da violência na agenda da saúde: trajetória histórica. Ciência \& Saúde Coletiva, Rio de Janeiro, v.11, n. 2, p. 75-383, abr./ jun. 2006.

NOVAES, R. R. Juventudes Cariocas: mediações, conflitos e encontros culturais. In: VIANNA, H. (Org.). Galeras cariocas: territórios de conflitos e encontros culturais. Rio de janeiro, UFRJ, 1997. p. 119-160.

OLIVEIRA, C. Sobrevivendono Inferno: a violênciajuvenil na contemporaneidade. Porto Alegre: Meridional, 2001.

PERALVA, A. T. O jovem como modelo cultural. Revista Brasileira de Educação, Campinas, $\mathrm{n}^{\circ}$ 5, p. 15-24, maio/ago. 1997. Número especial: Juventude e Contemporaneidade.

RABELLO DE CASTRO, L. Da invisibilidade à ação: crianças e jovens na construção da cultura. In: . Crianças e jovens na construção da cultura. 1. ed. Rio de Janeiro: FAPERJ, 2001, p 19-46. v. 1.

RIFIOTIS, T. Nos campos da violência: diferença e positividade. Antropologia em Primeira Mão, Florianópolis, v. 19, p. 1-19, 1997.

RIFIOTIS, T. Alice do outro lado do espelho: revisitando as matrizes do campo das violências e dos conflitos sociais. Revista de Ciências Sociais, Fortaleza, v. 37, n. 2, p. 27-33, jul./dez. 2006.

SALES, M. A. (In) Visibilidade perversa: adolescentes infratores como metáfora da violência. São Paulo: Cortez, 2007.

SÁNCHEZ-JANKOWSKI, M. As gangues e a imprensa, a produção de um mito nacional. Revista Brasileira de Educação, Campinas, n. 5, p 180-198, maio/ ago. 1997. Número especial: Juventude e Contemporaneidade.

SÁNCHEZ VÁZQUEZ, A. Filosofia da práxis. São Paulo: Expressão Popular, 1990. 
SAWAIA, B. O sofrimento ético-político como categoria de análise da dialética exclusão/inclusão. In: . As artimanhas da exclusão: análise psicossocial e ética da desigualdade social. Petrópolis, Vozes, 2006, p. 97-118.

TRILHA SONORA DO GUETO. V. L também ama. In: . Us Fracu Num Tem Veiz. São Paulo: Sky Blue Music, p2004. 1 CD. Faixa 14.

WAISELFISZ, J. J. Mesa Redonda 1: Subsídios para a construção de uma prática qualificada do psicólogo no atendimento aos adolescentes em privação de liberdade. In:_. Relatório do Seminário Nacional: A Atuação dos Psicólogos junto aos adolescentes privados de liberdade. Brasília: Conselho Federal de Psicologia, 2006, p. 45-69.

ZALUAR, A. Gangues, galeras e quadrilhas: globalização, juventude e violência. In: VIANNA, H. (Org.). Galeras cariocas: territórios de conflitos e encontros culturais. Rio de janeiro: UFRJ, 1997. p. 17-57.

ZALUAR, A. Violência e crime. In: . O que ler na Ciência Social Brasileira. São Paulo: Sumaré, 1999. p. 13-107. v.1: Antropologia.

Recebido em: fevereiro de 2010 Aceito em: agosto de 2010 
